\title{
EFFECT OF POSTHARVEST CALCIUM CHLORIDE VACUUM INFILTRATION ON THE SHELF LIFE AND QUALITY OF TOMATO (CV. 'THILINA')
}

\author{
P.A.W.A.N.K. Senevirathna ${ }^{1}$ and W.A.M. Daundasekera ${ }^{2} *$ \\ ${ }^{1}$ Postgraduate Institute of Science, University of Peradeniya, Sri Lanka. \\ ${ }^{2}$ Department of Botany, Faculty of Science, University of Peradeniya, Sri Lanka. \\ Accepted 20 May 2010
}

\begin{abstract}
Mature turning tomato fruits (cv. 'Thilina') were treated with four different concentrations of $\mathrm{CaCl}_{2}$ $(0 \%, 2 \%, 4 \%$, and $6 \%$ aqueous solutions) using different modes of application; dipping, vacuum infiltration and pressure infiltration, with a view to improve the shelf life and quality. Fruits vacuum infiltrated at $-20 \mathrm{kPa}$ and treated with the four different concentrations of $\mathrm{CaCl}_{2}$ were assessed for $\mathrm{pH}$, total soluble solids (TSS) content, percentage titratable acidity (\%TA) and firmness. Total calcium content in the inner and outer pericarp tissues was estimated and the path of calcium infiltration was revealed using black ink. Vacuum infiltration was found to be the most effective treatment with respect to shelf life extension. Also, $6 \% \mathrm{CaCl}_{2}$ treatment at $-20 \mathrm{kPa}$ was the best in terms of extension of shelf life (by $92 \%$ ) and in keeping the postharvest quality of tomatoes compared to the untreated fruits kept at $28{ }^{\circ} \mathrm{C}$. Fruit firmness significantly increased with $\mathrm{CaCl}_{2}$ application. Delay in fruit colour development, lowering of ethylene production rates and delay in the time taken to reach the ethylene climacteric were observed with increased $\mathrm{CaCl}_{2}$ concentration. Treatment with $\mathrm{CaCl}_{2}$ did not have a considerable effect on fruit $\mathrm{pH}$, TSS or \% TA. The amount of total calcium in the inner and outer pericarp regions increased significantly with calcium application. The stem end scar was found to be the main pathway of $\mathrm{CaCl}_{2}$ infiltration in to fruits.
\end{abstract}

Key words: firmness, ethylene, ripening

\section{INTRODUCTION}

Tomato (Lycopersicon esculentum, Mill) is one of the most widely consumed vegetables in the world. For fruits like tomato, postharvest handling is as critical as production practices due to their delicate nature. Postharvest losses may take place at any stage in the handling system from harvesting through storage and marketing to final delivery to the consumer. Due to its climacteric nature, tomato is highly perishable especially in tropical and subtropical areas. Nearly $30-50 \%$ of the produce is lost after harvest because of inadequate handling and preservation (Inaba and Crandall, 1986).

Calcium ions are known to be involved in many physiological processes in fruits and vegetables, playing an important role in maintaining their quality. Increased $\mathrm{Ca}^{+2}$ levels have been shown to reduce respiration and ethylene production rates in a variety of fruit crops including tomato (Garcia et al., 1995). Effectiveness of the method of $\mathrm{CaCl}_{2}$ applications as a postharvest treatment differs among crops (Shorter and Joyce, 1998). For green-harvested tomato, vacuum infiltration was found to be effective in rapid reduction of ethylene production and respiration rates at 20 ${ }^{\circ} \mathrm{C}$, which was also dependent upon vacuum pressure and the concentration of $\mathrm{CaCl}_{2}$ used (Wills et. al., 1977; Wills and Tirmazi, 1979). It was further reported that ripening could be delayed only when the calcium content of fruits was raised to a level greater than $40 \mathrm{mg} / 100 \mathrm{~g}$ fresh weight (Wills et. al., 1977).

In the present study the effect of different modes of $\mathrm{CaCl}_{2}$ application at different concentrations was examined for a local tomato variety 'Thilina' harvested at commercial maturity. The postharvest quality of fruits treated with $\mathrm{CaCl}_{2}$ was evaluated under normal tropical storage conditions. The likely pathways of calcium were also studied using a watersoluble dye. 


\section{MATERIALS AND METHODS}

\section{Plant material}

Mature turning $\left(1 / 10^{\text {th }}\right.$ orange) tomatoes (cv. 'Thilina') were collected from a commercial field at Kalugamuwa, Sri Lanka, $\left(080^{\circ} 35^{\prime}\right.$ longitude and $007^{\circ} 15^{\prime}$ latitude). Fruits visibly free from disease and defects were selected for the experiments. Fruits were packed into a threeply corrugated fiber board box (CFB) with ventilation holes and lined with moulded pulp trays. Tomatoes were transported to the Plant Pathology Laboratory at the Department of Botany, University of Peradeniya, within one hour after harvest. Fruits were then rinsed with tap water and dipped in an aqueous solution of $1 \%$ sodium hypochlorite for $1 \mathrm{~min}$ for surface sterilization. Fruits were then allowed to drain for $30 \mathrm{~min}$ and used in the subsequent experiments.

Experiment 1: Mode of $\mathrm{CaCl}_{2}$ treatment on the shelf life of tomatoes

Dip treatment with $\mathrm{CaCl}_{2}$

Tomatoes were separated into 10 batches, each having 3 replicate fruits. Fruits were dipped separately in 3 different concentrations of calcium chloride $(2 \%, 4 \%$ or $6 \%)$ for 10,20 and $30 \mathrm{~min}$. They were allowed to drain and thereafter held under ambient conditions $(28 \pm 2$ ${ }^{\circ} \mathrm{C}$ and relative humidity $\left.65 \pm 2 \%\right)$. Fruits dipped in distilled water $\left(0 \% \mathrm{CaCl}_{2}\right)$ for the same time durations served as controls.

\section{Vacuum infiltration}

Calcium chloride solutions of $2 \%, 4 \%$ and $6 \%$ concentrations were used. The three replicate fruits for each concentration were immersed in each solution of $\mathrm{CaCl}_{2}$ and subjected to vacuum pressures of $-10,-20$ and $30 \mathrm{kPa}$ for 2-3 minutes (Perera and Karunaratne, 2002). After release of the vacuum, the fruits were kept immersed in the same solution for a further 5 min (Wills and Tirmazi, 1979) in order to facilitate a rapid influx of $\mathrm{CaCl}_{2}$ solution (Weerakoon et. al., 2006). The same procedure was followed for the control set of fruits using distilled water. Fruits were allowed to drain for 30 min upon removal from the dip, and stored in clean, dry plastic trays at room temperature (28 $\left.\pm 2{ }^{\circ} \mathrm{C}\right)$ and relative humidity $(65 \pm 2 \%)$.

\section{Pressure infiltration}

Calcium chloride infiltration was performed by slightly modifying the method of Perera and Karunaratne (2002). $\mathrm{CaCl}_{2}$ solutions of $2 \%, 4$ $\%$ and $6 \%$ concentrations were prepared and the three replicate fruits for each concentration were immersed in the respective solutions and pressures of 10, 20 and $30 \mathrm{kPa}$ (Wills and Tirmazi, 1979) were applied for 2-3 min. After release of the pressure, fruits were kept immersed in the same solutions for a further 5 min. Thereafter, the fruits were stored as described above.

\section{Shelf life of fruits}

The shelf life of fruits was estimated as the number of days taken to reach the red ripe stage of the peel. The peel colour was rated visually using a self-prepared scale of $0-5$ based on the U.S. Department of Agriculture classifications (Anon, 1975). The colour development scale for ripening was: 0 - green; 1 - turning; 2 - one third pink; 3 - two third pink; 4 - orange and 5 - red.

Experiment 2: Effect of vacuum infiltration with different concentrations of $\mathrm{CaCl}_{2}$ on physicochemical changes in harvested tomatoes

Vacuum infiltration was found to be the only effective mode of treatment with $\mathrm{CaCl}_{2}$ in extending the shelf life of tomato. Therefore, fruits were vacuum infiltrated with $2 \%, 4 \%$ and $6 \% \mathrm{CaCl}_{2}$ solutions under $-20 \mathrm{kPa}$ as described in Experiment 1. Thereafter, assessments were carried out for skin colour, total calcium content, rate of ethylene production, firmness, percentage titratable acidity (\%TA), total soluble solids (TSS) content and $\mathrm{pH}$.

\section{Estimation of the total calcium content in tomato tissues}

The amount of calcium in the fruit tissue was determined by slightly modifying the method of Shorter and Joyce (1998). Locular gel tissues were removed and tissues from the inner and outer pericarp regions were collected separately and dried in an oven at $80{ }^{\circ} \mathrm{C}$ until they reached a constant weight. The samples were then ground to a fine powder using mortar and pestle. Then, $0.5 \mathrm{~g}$ from each sample was ashed in a muffle furnace at $525{ }^{\circ} \mathrm{C}$. The ash was dissolved in $5 \mathrm{ml}$ of $20 \% \mathrm{HCl}$, filtered and made up to a volume of $50 \mathrm{ml}$ with deionized water. Calcium was measured using flame emission spectrophotometer (Jenway-PFP 7, U.K.). Tissue $\mathrm{Ca}^{2+}$ concentration was expressed as $\mathrm{mg}$ $\mathrm{Ca}^{2+} / \mathrm{g}$ dry weight.

\section{Rate of ethylene production}

Ethylene production rates were measured by slightly modifying the method described by Hoeberichts et al. (2002). Individual tomatoes were incubated in air-tight bottles for $1 \mathrm{~h}$. At the end of the incubation period, $1 \mathrm{ml}$ gas samples were withdrawn from the headspace of the bottle 
using an airtight syringe and injected in to a gas chromatograph. Quantification of ethylene was carried out on a gas chromatograph (Agilent $4890 \mathrm{D}, \mathrm{USA})$ at an oven temperature of $75^{\circ} \mathrm{C}$ on a $2.0 \mathrm{~m}$ (length) $\times 3 \mathrm{~mm}$ (internal diameter) column packed with porapack Q (Hewlett Packard Co., USA). The carrier gas was Helium at $25 \mathrm{ml} \mathrm{min}^{-1}$ and the chromatograph was fitted with a flame ionization detector, which was set to $250{ }^{\circ} \mathrm{C}$. The injector temperature was set to $125^{\circ} \mathrm{C}$ and hydrogen gas pressure was set at 140 $\mathrm{kPa}$. The air pressure was set at $200 \mathrm{kPa}$. Data was collected using the Agilent GC chemstation software package (Rev.A.08.03 - 847). The gas chromatograph was calibrated against $10.1 \mu \mathrm{ll}^{-1}$ standard ethylene (Scott Specialty Gases, USA). Ethylene production rate was expressed as $\mu \mathrm{kg}^{-}$ ${ }^{1} \mathrm{~h}^{-1}$.

\section{Firmness of tomatoes}

Fruit firmness was measured using a handheld penetrometer (Forestry Suppliers Inc., U.K). One reading from each replicate fruit was taken from the middle, one third of the fruit, and the mean was calculated.

\section{Percentage titratable acidity (\% TA)}

$20 \mathrm{ml}$ of juice from a fruit was squeezed and diluted up to $50 \mathrm{ml}$ with distilled water and 10 $\mathrm{ml}$ aliquots were titrated with $0.1 \mathrm{M} \mathrm{NaOH}$ using phenolphthalein as the indicator (Wills and $\mathrm{Ku}, 2001$ ).

\section{Total soluble solids (TSS) content}

Juice from tomatoes was squeezed and the TSS $\left(\right.$ Brix $\left.^{\circ}\right)$ was determined using a hand held refractometer (Model, 121, Yagami International Ltd, Japan) (Wills and Ku, 2001).

\section{pH}

$\mathrm{pH}$ was measured using a flat ended digital $\mathrm{pH}$ meter for surfaces (Model TPS aqua V.1, Australia). Three readings were taken from each fruit by removing the peel (exocarp). Readings were taken $1 \mathrm{~cm}$ away from stem end, $1 \mathrm{~cm}$ away from blossom end and from the middle one third of the fruit, and the means were calculated (Weerakoon et. al., 2006).

Experiment 3: Revealing the path of calcium penetration

Black ink (Hero, China) was added to $4 \%$ $\mathrm{CaCl}_{2}$ solution. Vacuum infiltration of fruits was carried out at $-20 \mathrm{kPa}$ for $3 \mathrm{~min}$ in $\mathrm{CaCl}_{2}$-ink solution. After $24 \mathrm{~h}$, individual fruits were sectioned at $0,1 / 41$ and $24 \mathrm{~h}$ after infiltration for visual inspection of the path of dye and $\mathrm{CaCl}_{2}$ penetration (modified method of Shorter and Joyce, 1998).

\section{Experiment design and data analysis}

All experiments were arranged in completely randomized design (CRD) as follows: Experiment 1: The factorial design was 2 factor (4 concentrations $\times 12$ treatments), where the number of replicates $(n)=3$. Data were subjected to analysis using a general analysis of variance (ANOVA) function. Experiment 2: The factorial design was (4 concentrations $\mathrm{x} 4$ treatments), each treatment having 3 replicates and the data were subjected to one way ANOVA. Experiment 3: the factorial design was 2 factor (4 parameters i.e. firmness, $\mathrm{pH}$, \% TA and TSS with 4 concentrations) and data were analyzed using one way ANOVA.

\section{RESULTS}

Experiment 1: Effect of mode of $\mathrm{CaCl}_{2}$ treatment on the shelf life of tomato ( $\mathrm{cv}$. 'Thilina')

Vacuum infiltration with $6 \% \mathrm{CaCl}_{2}$ was found to be the most effective method among all three modes of treatment tested for extending the shelf life of tomatoes (Table 1). The shelf life increased with higher vacuum pressure in both $4 \%$ and $6 \% \mathrm{CaCl}_{2}$ solutions. Although vacuum infiltration under $-30 \mathrm{kPa}$ with $6 \% \mathrm{CaCl}_{2}$ gave the longest shelf life, it resulted in oozing out of juice from the stem end scar which led to the growth of fungi at the red-ripe stage of tomato fruits (data not shown). Of the application methods, $\mathrm{CaCl}_{2}$ dip treatment and pressure infiltration did not have an effect on the shelf life of tomatoes (Table 1). Therefore, evaluation of postharvest physico-chemical parameters was carried out only with fruits subjected to vacuum infiltrated at $-20 \mathrm{kPa}$.

Experiment 2: Effect of vacuum infiltration with different concentrations of $\mathrm{CaCl}_{2}$ on physicochemical changes in harvested tomatoes

\section{Fruit Skin colour}

Treatment with $\mathrm{CaCl}_{2}$ concentrations of $4 \%$ and $6 \%$ at $-20 \mathrm{kPa}$ delayed colour development in tomato fruits compared to untreated fruits (Fig. 1). There was no difference in the pattern of change in skin colour in $\mathrm{CaCl}_{2}$ treated fruits versus untreated fruits. 


\section{Total calcium content}

The total calcium content in both inner and outer pericarp regions of fruits treated with $\mathrm{CaCl}_{2}$ were significantly higher $(\mathrm{p}=0.05)$ than those of untreated fruits (Table 2). The $\mathrm{Ca}^{+2}$ levels in

tissues increased significantly with increasing levels of $\mathrm{Ca}^{+2}$ in the solution. Also, significantly higher levels of $\mathrm{Ca}^{+2}$ were detected in the inner pericarp region than in the outer pericarp of treated fruits

\section{Ethylene production rate}

$\mathrm{CaCl}_{2}$ treated tomatoes produced ethylene at significantly lower levels than untreated fruits at the early stages of incubation (Fig. 2). Also, treatment with $\mathrm{CaCl}_{2}$ delayed the time taken to reach ethylene climacteric in fruits. Furthermore, the magnitude of the climacteric peak was lowered to a certain extent by $\mathrm{CaCl}_{2}$ treatment.

\section{Fruit firmness}

$\mathrm{CaCl}_{2}$ treated fruits showed significantly higher firmness compared to untreated fruits at the end of the shelf life (red-ripe stage) (Fig. 3). The increase in firmness was found to have a positive relationship with the treated $\mathrm{CaCl}_{2}$ concentration.
Total soluble solids (TSS) content, \%TA and pH

The TSS content in fruits significantly increased with $\mathrm{CaCl}_{2}$ treatment. However, there was no consistent relationship between $\mathrm{CaCl}_{2}$ treatment and the TSS content of tomato fruits at the end of the shelf life (Table 3). Similarly, there was no consistent relationship between $\mathrm{CaCl}_{2}$ treatment and \% TA of tomato fruits (Table 3). However, with $6 \% \quad \mathrm{CaCl}_{2}$ concentration a significant reduction in $\% \mathrm{TA}$ was observed. Although it was expected that $\mathrm{pH}$ would increase with higher $\mathrm{CaCl}_{2}$ levels according to \% TA values, $\mathrm{pH}$ was reduced to insignificant levels with the increase of $\mathrm{CaCl}_{2}$ concentration (Table 3).

\section{Experiment 3: Path of calcium penetration}

The ink added to the $\mathrm{CaCl}_{2}$ solution had traveled fast, mainly through the stem end scar and after about $15 \mathrm{~min}$ it had almost reached the core of the fruit (Fig. 4). There were no visible signs of the $\mathrm{CaCl}_{2}$ - ink solution entering through other parts of the fruit skin.

Table 1. Shelf life of tomato fruits (cv. 'Thilina') treated with different concentrations of $\mathrm{CaCl}_{2}$ using three modes of application ( Storage conditions: $28 \pm 2{ }^{\circ} \mathrm{C}$ and $65 \pm 2 \% \mathrm{RH}$ )

\begin{tabular}{cccccc}
\multirow{2}{*}{ Mode of $\mathbf{C a C l}_{2}$ treatment } & Treatment & \multicolumn{5}{c}{ Shelf life (days)* } \\
\cline { 3 - 6 } & & $\mathbf{0 \%} \mathbf{C a C l}_{\mathbf{2}}$ & $\mathbf{2 \%} \mathbf{C a C l}_{\mathbf{2}}$ & $\mathbf{4 \%} \mathbf{C a C l}_{\mathbf{2}}$ & $\mathbf{6 \%} \mathbf{C a C l}_{\mathbf{2}}$ \\
\hline \multirow{2}{*}{$\begin{array}{c}\text { Vacuum } \\
\text { infiltration }\end{array}$} & $-30 \mathrm{kPa}$ & Damaged & $5 \mathrm{~d}$ & $11 \mathrm{~b}$ & $14 \mathrm{a}$ \\
& $-20 \mathrm{kPa}$ & Damaged & $5 \mathrm{~d}$ & $7 \mathrm{c}$ & $10 \mathrm{~b}$ \\
& $-10 \mathrm{kPa}$ & $5 \mathrm{~d}$ & $5 \mathrm{~d}$ & $5 \mathrm{~d}$ & $5 \mathrm{~d}$ \\
\hline \multirow{2}{*}{ Pressure } & $30 \mathrm{kPa}$ & Damaged & $5 \mathrm{~d}$ & $6 \mathrm{~d}$ & $8 \mathrm{c}$ \\
infiltration & $20 \mathrm{kPa}$ & Damaged & $5 \mathrm{~d}$ & $5 \mathrm{~d}$ & $6 \mathrm{~d}$ \\
& $10 \mathrm{kPa}$ & $5 \mathrm{~d}$ & $5 \mathrm{~d}$ & $5 \mathrm{~d}$ & $5 \mathrm{~d}$ \\
\hline \multirow{2}{*}{ Dipping } & $30 \mathrm{mins}$ & $5 \mathrm{~d}$ & $5 \mathrm{~d}$ & $5 \mathrm{~d}$ & $5 \mathrm{~d}$ \\
& $20 \mathrm{mins}$ & $5 \mathrm{~d}$ & $5 \mathrm{~d}$ & $5 \mathrm{~d}$ & $5 \mathrm{~d}$ \\
& $10 \mathrm{mins}$ & $5 \mathrm{~d}$ & $5 \mathrm{~d}$ & $5 \mathrm{~d}$ & $5 \mathrm{~d}$ \\
\hline
\end{tabular}

* Time taken to reach fruit skin colour Index 5

Values are means of three replicates. Mean values followed by different letters are significantly different at $\mathrm{p}=0.05$ 


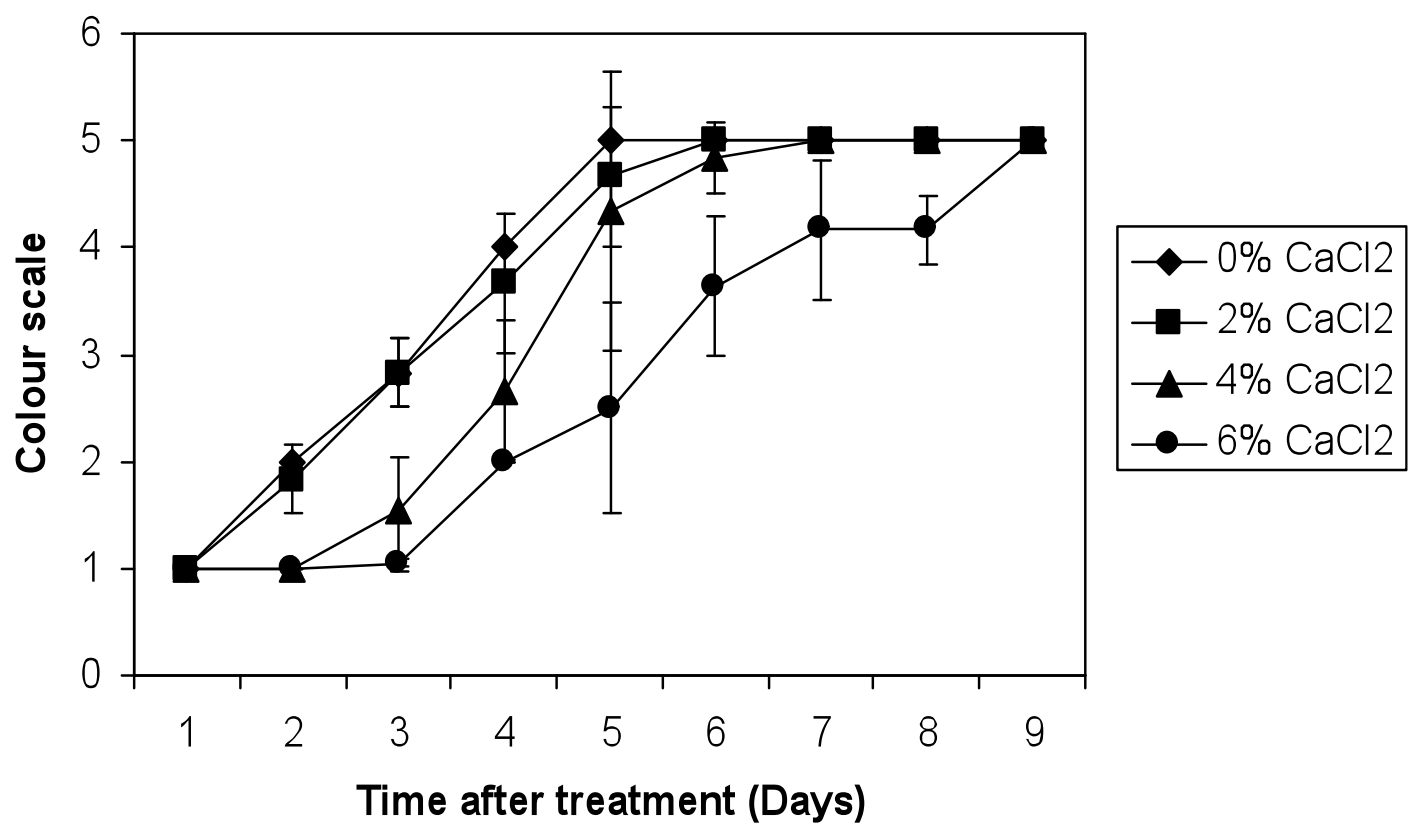

Figure 1. Effect of vacuum infiltration (at $-20 \mathrm{kPa}$ ) with different concentrations of $\mathrm{CaCl}_{2}$ on the skin colour change in tomatoes (cv. 'Thilina') stored under $28 \pm 2{ }^{\circ} \mathrm{C}$ and $65 \pm 2 \% \mathrm{RH}$.

(Vertical bars represent the standard error of mean)

(Values are means of three replicates)

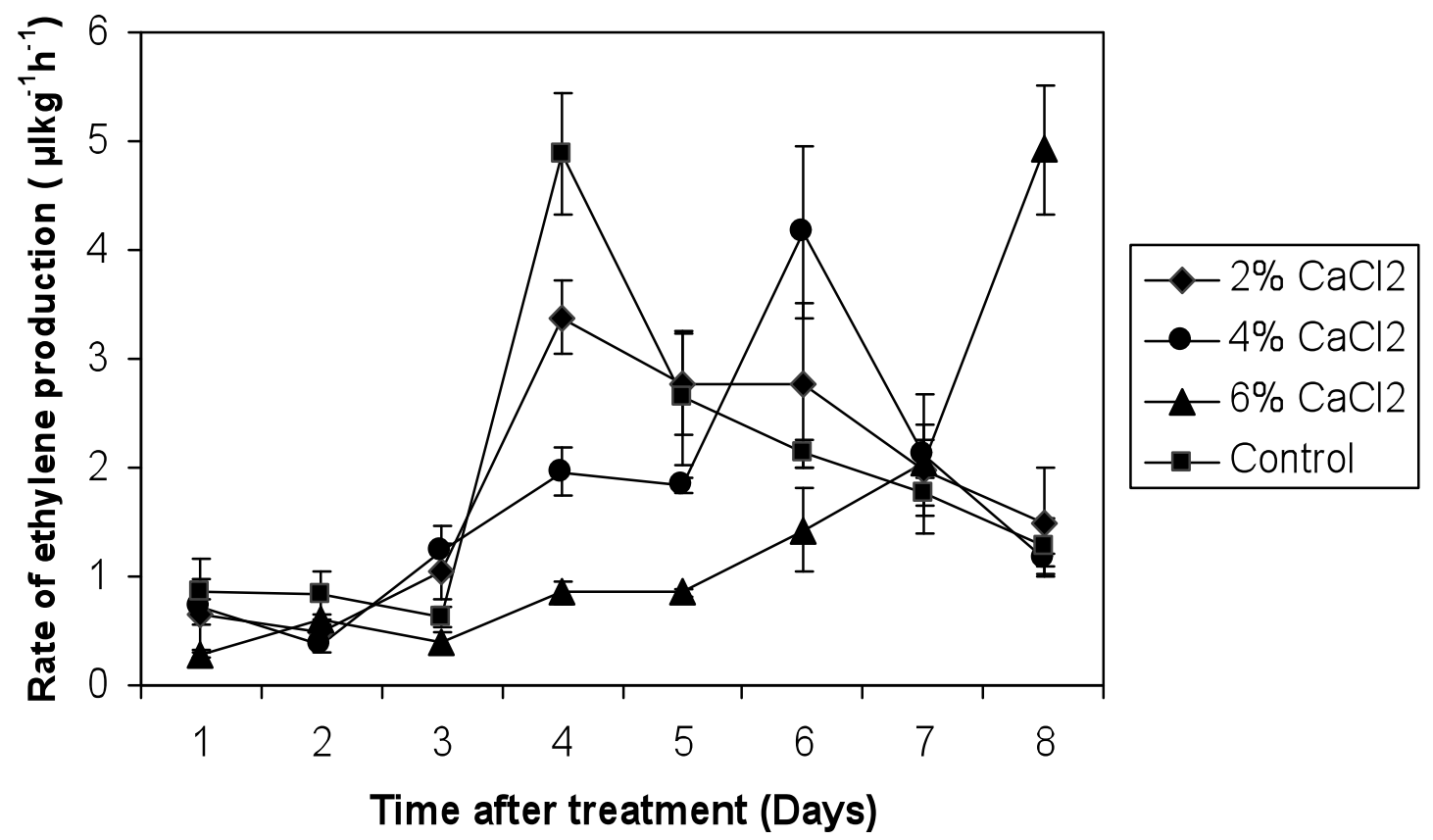

Figure 2. Effect of vacuum infiltration (at $-20 \mathrm{kPa}$ ) with different concentrations of $\mathrm{CaCl}_{2}$ on the rates of ethylene production in tomato (cv. 'Thilina')

(Vertical bars represent the standard error of mean)

(Values are means of three replicates) 


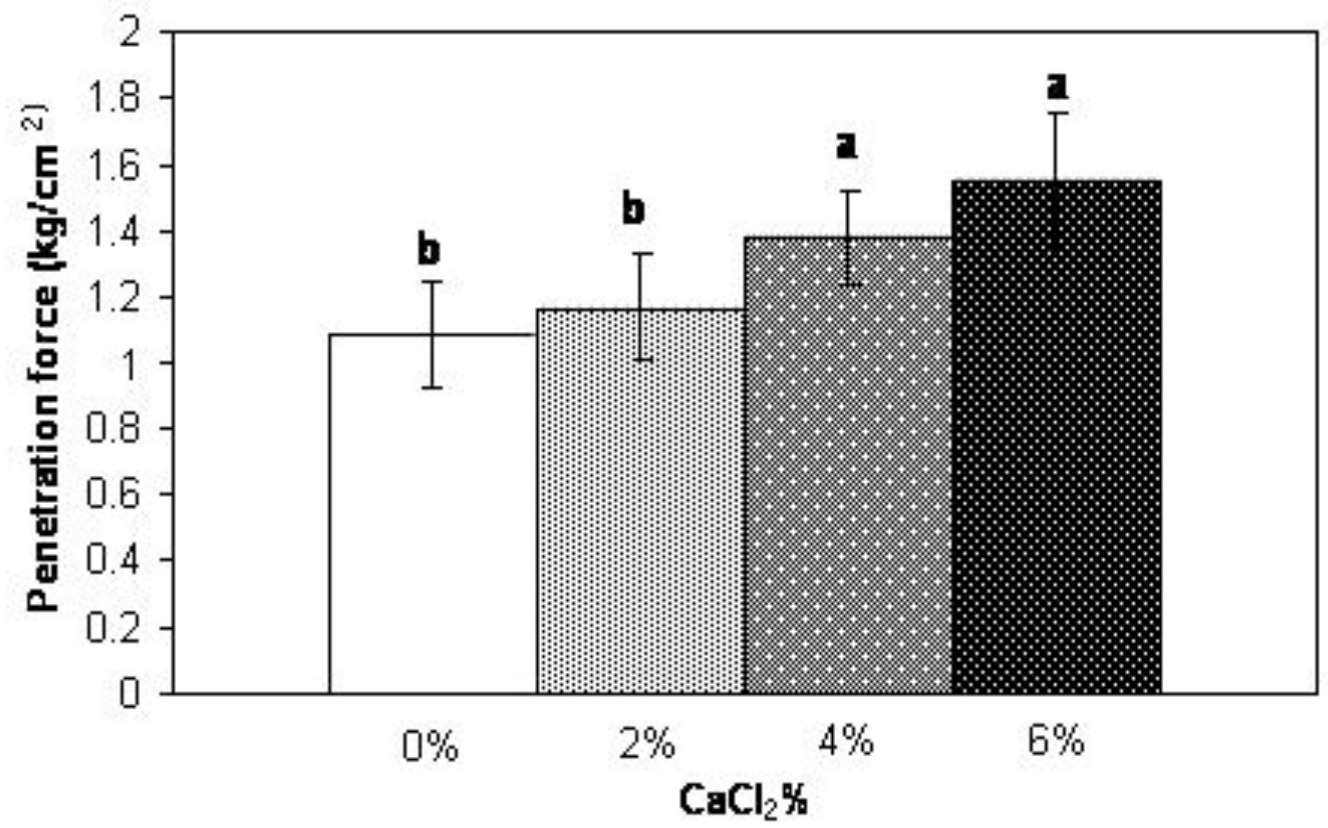

Figure 3. Effect of vacuum infiltration (at $-20 \mathrm{kPa}$ ) with different concentrations of $\mathrm{CaCl}_{2}$ on the firmness in tomatoes (cv. 'Thilina') at red-ripe stage (Colour Index 5).

(Vertical bars represent the standard error of mean)

(Values in each column followed by different letters are significantly different at $\mathbf{p}=\mathbf{0 . 0 5}$ )

(Values are the means of three replicates)

Table 2. The $\mathrm{Ca}^{2+}$ content in the inner and outer pericarp tissues of tomatoes (cv. 'Thilina') after vacuum infiltration with different concentrations of $\mathrm{CaCl}_{2}$ for 2 min under $-20 \mathrm{kPa}$.

$\% \mathrm{CaCl}_{2}$

$$
\mathrm{Ca}^{2+} \text { content (mg/g dry weight) }
$$

$\begin{array}{lll}0 & 20.7 \mathrm{f} & 28.8 \mathrm{c} \\ 2 & 22.8 \mathrm{f} & 31.3 \mathrm{~b} \\ 4 & 24.3 \mathrm{f} & 35.8 \mathrm{~b} \\ 6 & 27.5 \mathrm{c} & 43.8 \mathrm{a}\end{array}$

Values are means of three replicates.

Mean values in each column followed by different letters are significantly different at $p=0.05$ 


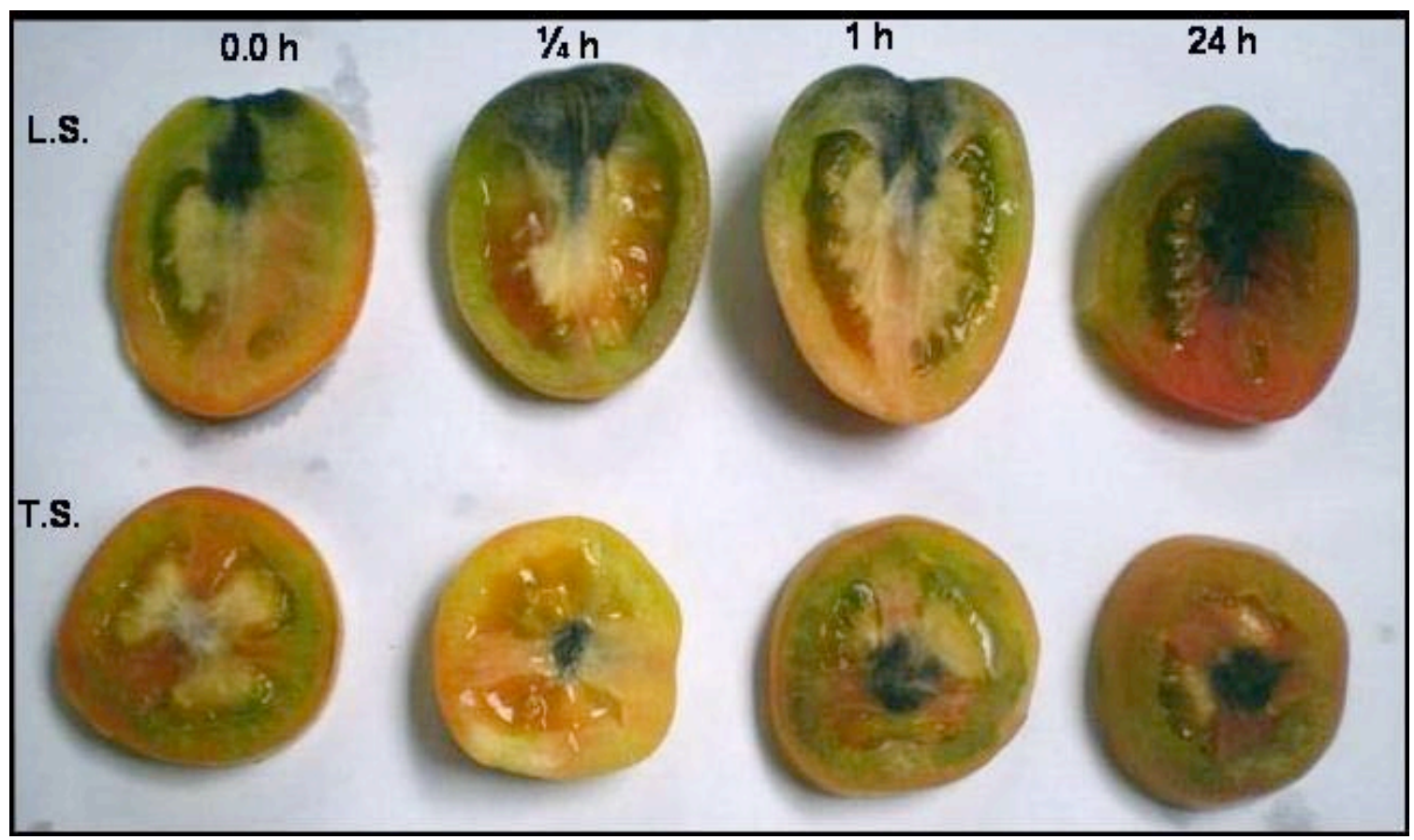

Figure 4. Longitudinal sections (L.S.) and Transverse sections (T.S.) of tomato fruit at different time intervals after vacuum infiltration (at $-20 \mathrm{kPa}$ for 2 minutes) with $4 \% \mathrm{CaCl}_{2}$ solution containing black ink.

Table 3. Total soluble solids content, percentage titratable acidity and pH of tomatoes (cv. 'Thilina') infiltrated with different concentrations of $\mathrm{CaCl}_{2}$ at $-20 \mathrm{kPa}$ vacuum pressure and stored at $28 \pm{ }^{0} \mathrm{C}$ until red-ripe.

$\% \mathrm{CaCl}_{2}$
Total Soluble Solids

(TSS) content

\section{Percentage titratable acidity (TA \%)}

pH

\begin{tabular}{cccc}
\hline 0 & $3.30 \mathrm{~b}$ & $7.07 \mathrm{a}$ & $4.55 \mathrm{a}$ \\
2 & $3.87 \mathrm{a}$ & $7.58 \mathrm{a}$ & $4.51 \mathrm{a}$ \\
4 & $3.80 \mathrm{a}$ & $7.04 \mathrm{a}$ & $4.48 \mathrm{~b}$ \\
6 & $3.20 \mathrm{~b}$ & $6.59 \mathrm{~b}$ & $4.49 \mathrm{a}$
\end{tabular}

Values are means of three replicates.

Mean values in each column followed by different letters are significantly different at $p=0.05$ 


\section{DISCUSSION}

The technique of vacuum infiltration has been reported to be effective in raising the calcium content in fruits like mango (Tirmazi and Wills, 1981; Shorter and Joyce, 1998), avocado (Tingwa and Young, 1974), tomato (Wills et. al., 1977, Wills and Tirmazi, 1979) and pears (Wills et. al., 1982). Higher concentrations viz.12\% $\mathrm{CaCl}_{2}$ may result in complete inhibition of ripening as shown by the inhibition of fruit colour development in certain fruits (Wills et. al., 1977). Reasons for the failure in skin colour development may be an effect of $\mathrm{CaCl}_{2}$ on the ethylene generating cycle, which affects the synthesis of the pigment lycopene during the process of ripening (Njoroge et. al., 1998). The change in tomato fruit colour appears to be dependent also upon the vacuum applied, maturity of fruits and the storage temperature (Moline, 1980).

The total $\mathrm{Ca}^{2+}$ in tomato tissue showed a positive relationship with the $\mathrm{CaCl}_{2}$ concentrations used for infiltration. There was a significant increase in $\mathrm{Ca}^{2+}$ in the inner pericarp and a lesser increase in the outer pericarpal region. As revealed by the dye penetration test, most of the treatment solutions had entered through the stem end scar. This may have led to a greater accumulation of calcium in the inner pericarpal region. The amount of $\mathrm{Ca}^{2+}$ in the outer pericarp was relatively low, which may possibly have entered through the stomata. Wills et. al. (1977) have reported that a 3-fold increase in calcium level (compared to untreated fruits) is needed to produce any noticeable retardation in the ripening of green tomato (cv. 'Rouge de Mamande') at $20{ }^{\circ} \mathrm{C}$. However, in the present study, even a 1.4 fold increase in $\mathrm{Ca}^{2+}$ levels (compared to the control) was effective in retarding ripening. These observed differences in different studies may be due to the relatively higher storage temperatures $\left(27 \pm 2{ }^{\circ} \mathrm{C}\right)$, cultivar difference and also the differences in the stage of fruit maturity at the time of $\mathrm{CaCl}_{2}$ treatment.

The time taken to reach the ethylene climacteric was also delayed with the increase in $\mathrm{CaCl}_{2}$ concentration. It has been shown that once the intracellular calcium concentration increased to at least $1 \mu \mathrm{M}$ (Saunders and Helper, 1983), calcium is bound to calmodulin, which is one of the most common intracellular calcium receptors and the accruing calcium-calmodulin complex modulates many physiological processes. Njoroge et. al. (1998) found that calmodulin is involved in the calcium inhibited ethylene biosynthesis. Calcium may be inactivating the Ethylene Forming Enzyme in the ethylene biosynthetic pathway via calcium-calmodulin mediated reactions.

There was a positive relationship between tomato fruit firmness and the treated $\mathrm{CaCl}_{2}$ concentration. The stability of the cell walls may probably be attributed to the formation of cation cross bridges between uronic acid groups (Sams et. al., 1993) as evident from increased firmness levels in apples (Wienke, 1980). With $6 \% \mathrm{CaCl}_{2}$ treatment, the higher levels of calcium accumulated in the tomato pericarp may have contributed to significantly higher fruit firmness through such cross-linking. Generally, calcium is found in the cell walls as calcium pectate (Agusti et. al., 2004). Vacuum infiltration of calcium may also have increased the bound calcium content in the tomato tissues contributing to an increase in the fruit firmness (Hong and Lee, 1999). The higher firmness at eating-ripe stage of tomato may be attributed to the inhibited action of polygalacturonase (Doesburg, 1975), the enzyme which mediates the degradation of pectates during ripening.

Calcium treatment has little effect on TSS content, $\mathrm{pH}$ or TA in tomato fruits. This observation agrees with reports on fruits like mango (Tirmazi and Wills, 1981) and strawberry (De Sauza et. al., 1999). However, the effect of $\mathrm{CaCl}_{2}$ treatment on chemical parameters appear to be commodity-dependent.

In conclusion, application of $6 \% \mathrm{CaCl}_{2}$ at -20 $\mathrm{kPa}$ vacuum pressure could be recommended as a commercial postharvest treatment for tomato under tropical storage conditions. Extension of the shelf life may be attributed mainly to the increased firmness and retarded ethylene production rates in $\mathrm{CaCl}_{2}$ treated fruits. Furthermore, evaluation of sensory parameters with a trained taste panel may be useful to confirm the acceptability of $\mathrm{CaCl}_{2}$ treatment in terms of flavour quality of tomatoes.

\section{REFERENCES}

Agusti, M., Juan, M., Fuentes, A.M., Mesejo, C. and Almela, V. (2004). Calcium nitrate delays climacteric of persimmon fruit. Association of Applied Biologists 144: 65-69.

Anon (1975). Colour classification requirements in United States standards for grades of fresh tomatoes. U.S.D.A. Visual Aid TM-L-1. 
De Souza, A.L.B., Scalon, S.D.P.Q., Chitarra, M.I.F. and Chitarra, A.B. (1999). Postharvest application of strawberry fruits (Fragaria ananassa): Evaluation of fruit quality and postharvest life, Cienciae Agrotechnologia 23: 841-848.

Doesburg, J.J. (1975). Relation between the solubilization of pectin and the fate of organic acids during maturation of apples. Journal of the Science of Food and Agriculture 8: 206-216.

García, M.J., Ballesteros and Albi M.A. (1995). Effect of foliar applications of $\mathrm{CaCl}_{2}$ on tomato stored at different temperatures. Journal of Agricultural Food Chemistry 43: 9-12.

Hoeberichts, F.A., Linus, H.W., Van, D.P. and Woltering, E.J. (2002). Ethylene perception is required for the expression of tomato ripeningrelated genes and associated physiological changes even at advanced stages of ripening. Postharvest Biology and Technology 26: 125133.

Hong, J.H. and Lee, S.K. (1999). Effect of calcium treatment on tomato fruit ripening. Journal of Korean Society of Horticultural Science 40: 638-642.

Inaba, M. and Crandall, P.G. (1986). Cold-shock treatment of mature green tomatoes to delay colour development and increase shelf-life during room temperature storage. Proceedings of Florida State Horticultural Society 99: 143145.

Moline, H.E. (1980). Effects of vacuum infiltration of calcium chloride on ripening rate and chilling injury of fruit. Phytopathology 70: 691.

Njoroje, C.K., Kerbel, E.L. and Briskin, D.P. (1998). Effect of Calcium and Calmodulin antagonists on Ethylene biosynthesis in Tomato fruits. Journal of the Science of Food and Agriculture 76: 209-214.

Perera, A.N. and Karunaratne, A.M. (2002). Postharvest calcium chloride treatments do not help to increase shelf-life of bananas. Fruits 7 : 87-94.

Sams, C.E., Conway, W.S., Abbott, J.A., Lewis, R.J. and Ben Shalom, N. (1993). Firmness and decay of apples following postharvest pressure infiltration of calcium and heat treatment.
Journal of American Society of Horticultural Science 118: 623-627.

Saunders, M.J., Helper, P. K. (1983). Calcium antagonists and calmodulin inhibitors block cytokinin induced bud formation in Funaria. Development Biology 99: 41.

Scott, K.J. and Wills, R.B.H. (1977). Vacuum infiltration of calcium chloride: A method for reducing bitter pit and senescence of apples during storage at ambient temperatures. HortScence 12: 71-72.

Scott, K.J. and Wills, R.B.H. (1979). Effects of vacuum and pressure infiltration of calcium chloride and storage temperature on the incidence of bitter pit and low temperature breakdown of apples. Australian Journal of Agricultural Research 30: 917-928.

Shorter, A.J. and Joyce, D.C. (1998). Effects of partial pressure infiltration of calcium in to 'Kensington' mango fruit, Australian Journal of Experimental Agriculture 38: 287-294.

Tingwa, P.O. and Young, R.E. (1974). The effect of calcium on the ripening of avocado (Persea americana Mill.) fruits. Journal of American Society of Horticultural Science 99: 540-542.

Tirmazi, S.I.H. and Wills, R.B.H. (1981). Retardation of ripening of mangoes by postharvest application of calcium. Tropical Agriculture 58: 137-141.

Weeerakoon, A., Adikaram, N. and Abayasekara, C. (2006). Significance of host $\mathrm{pH}$ change during Colletotrichum musae infection of banana. Proceedings of the Peradeniya University Research sessions. Sri Lanka 2: 145.

Wienke, J. (1980). Autoradiographic localization of $45 \mathrm{Ca}$ and $36 \mathrm{Cl}$ after postharvest dipping of apple fruits. In. Mineral Nutrition of Fruit Trees. D. Atkinson, J.E. Jackson, R.O. Sharples, and W.M.Waller, eds. Butterworth's, London. 334336.

Wills, R.B.H., Tirmazi, S.I. and Scott, K.J. (1977). Use of calcium to delay ripening of tomatoes, HortScience 12: 551-552.

Wills, R.B.H. and Tirmazi, S.I.H. (1979). Effect of calcium and other minerals on ripening of tomatoes. Australian Journal of Plant Physiology 6: 221-227. 
Wills, R.B.H., Tirmazi, S.I. and Scott, K.J. (1982). Effect of postharvest application of calcium on ripening rates of pears \& bananas, Journal of Horticulture Science 57: 431 - 435.
Wills, R.B.H. and Ku, V.V.V. (2001). Use of 1MCP to extend the ripening of green tomatoes and post harvest life of ripe tomatoes. Postharvest Biology and Technology 26: 85-90. 